\title{
Insulin immuno-neutralization in chicken: effects on insulin signaling and gene expression in liver and muscle
}

\author{
Joëlle Dupont ${ }^{1}$, Sophie Tesseraud ${ }^{2}$, Michel Derouet ${ }^{2}$, Anne Collin $^{2}$, Nicole Rideau ${ }^{2}$, Sabine Crochet ${ }^{2}$, \\ Estelle Godet $^{2}$, Estelle Cailleau-Audouin ${ }^{2}$, Sonia Métayer-Coustard ${ }^{2}$, Michel J Duclos ${ }^{2}$, \\ Christian Gespach ${ }^{3}$, Tom E Porter ${ }^{4}$, Larry A Cogburn ${ }^{5}$ and Jean Simon ${ }^{2}$
}

${ }^{1}$ PRC (UMR 6175) and ${ }^{2}$ Station de Recherches Avicoles (UR 83), INRA, 37380 Nouzilly, France

${ }^{3}$ INSERM, U673 and Université Pierre et Marie Curie Paris 6, Hôpital Saint Antoine, 184 rue du Faubourg Saint Antoine, 75571 Paris, Cedex 12, France

${ }^{4}$ Department of Animal and Avian Sciences, University of Maryland, 1403 Animal Sciences, College Park, Maryland 20742, USA

${ }^{5}$ Department of Animal and Food Sciences, University of Delaware, 036 Townsend Hall, Newark, Delaware 19717-1303, USA

(Correspondence should be addressed to J Simon; Email: simon@tours.inra.fr)

\begin{abstract}
In order to evaluate the role of insulin in chicken, an insulin immuno-neutralization was performed. Fed chickens received 1 or 3 i.v. injections of anti-insulin serum (2-h intervals), while fed or fasted controls received normal serum. Measurements included insulin signaling cascade (at $1 \mathrm{~h}$ in liver and muscle), metabolic or endocrine plasma parameters (at 1 and $5 \mathrm{~h}$ ), and qRT-PCR analysis (at $5 \mathrm{~h}$ ) of 23 genes involved in endocrine regulation, metabolisms, and transcription. Most plasma parameters and food intake were altered by insulin privation as early as $1 \mathrm{~h}$ and largely at $5 \mathrm{~h}$. The initial steps of insulin signaling pathways including insulin receptor (IR), IR substrate-1 (IRS-1), and Src homology collagen and downstream elements: phosphatidylinositol 3-kinase (PI3K), Akt, GSK3, ERK2, and S6 ribosomal protein) were accordingly turned off in the liver. In the muscle, IR, IRS-1 tyrosine phosphorylation, and PI3K activity remained unchanged, whereas several subsequent steps were altered by
\end{abstract}

insulin privation. In both tissues, AMPK was not altered. In the liver, insulin privation decreased Egr1, PPAR $\gamma$, SREBP1, THRSP $\alpha$ (spot14), D2-deiodinase, glucokinase (GK), and fatty acid synthase (whereas D3-deiodinase and IGF-binding protein1 transcripts were up-regulated. Liver SREBP1 and GK and plasma IGFBP1 proteins were accordingly downand up-regulated. In the muscle, PPAR $\beta \delta$ and atrogin- 1 mRNA increased and Egr1 mRNA decreased. Changes in messengers were partly mimicked by fasting. Thus, insulin signaling in muscle is peculiar in chicken and is strictly dependent on insulin in fed status. The 'diabetic' status induced by insulin immuno-neutralization is accompanied by impairments of glucagon secretion, thyroid axis, and expression of several genes involved in regulatory pathways or metabolisms, evidencing pleiotropic effects of insulin in fed chicken.

Journal of Endocrinology (2008) 197, 531-542

\section{Introduction}

Despite the presence of hyperactive endogenous insulin circulating at 'normal' concentrations, chickens mimic a mammalian type 2 diabetic status by showing high glycemia and low sensitivity to exogenous insulin (Simon 1989, Akiba et al. 1999, Tokushima et al. 2003). Insulin dependency of chickens in the control of glycemia has, however, been shown in the fed state following extensive pancreatectomy or insulin immuno-neutralization (Simon 1989, Simon et al. 2000). In the fasted state, the control of glycemia is in contrast dependent on glucagon since fasted pancreatectomized chickens tend to develop hypoglycemia rather than hyperglycemia (Simon 1989). Similar conclusions have been obtained in ducks (Mirsky et al. 1964, Simon 1989 for a review).
Insulin receptor (IR) structure and two IR substrates have been characterized in chicken tissues: IR substrate 1 (IRS-1) and Src homology collagen protein (Shc) (Simon \& Taouis 1993, Taouis et al. 1996). Tyrosine phosphorylation of IR $\beta$-subunit, IRS-1 and Shc, and phosphatidylinositol 3-kinase (PI3K) activity appeared responsive to insulin status in the liver under several experimental conditions (fasting/re-feeding, chronic corticosterone treatment, genetically fat or lean chickens, or exogenous insulin challenge (Dupont et al. 1998a,b,c, 1999, 2004)). In contrast, these signaling steps (with the exception of Shc) were not altered in leg muscles by the various experimental conditions. This peculiar feature is consistent with an absence of change in tyrosine kinase activity observed for muscle IR purified from fasted/re-fed chickens (Adamo et al. 1987). However, in the chicken muscle, Shc 
tyrosine phosphorylation is stimulated by re-feeding or exogenous insulin (Dupont et al. 1998b, 2004). In addition to this apparent insulin refractoriness of muscle PI3K activity mentioned earlier, another peculiarity comes from the amount of $\mathrm{p} 85$ subunit and the activity of PI3K, which are largely higher in chicken muscle, when compared with the rat under the same conditions (Dupont et al. 2004). The apparent independence between insulin status and the level of IRS-1 tyrosine phosphorylation has been recently confirmed in chicken pectoral muscle, a pure glycolytic-type muscle (Duchêne et al. 2008c). To better understand the mechanisms of insulin action in chicken muscle, other components of insulin signaling have been recently characterized, namely the PKB/Akt, P70S6K1, and ERK2 kinases (Bigot et al. 2003a,b, Duchêne et al. 2008a,c). In mammals, activations of PKB/Akt and P70S6K1 are considered to be under the control of PI3K (White \& Kahn 1994). In chicken muscle (leg or pectoral muscle), PKB/Akt, P70S6K1, and ERK2 were all activated by re-feeding or exogenous insulin (Bigot et al. 2003a,b, Duchêne et al. 2008a,c). Under these conditions, an increase in the phosphorylation of IRS-1 on Ser 632/635 was observed in chicken muscle (Duchêne et al. 2008c). These specific serine residues are involved in the development of insulin resistance in mammals (Bouzakri et al. 2003). This unique feature of chicken muscle, an apparent refractoriness of early insulin signaling steps associated with normal sensitivity of more distal steps, represents a challenging model for insulin action. In the absence of an experimental chicken diabetes model (diabetogenic drugs are ineffective in this species as shown previously by Simon (1989)), we investigated the effect of insulin immuno-neutralization on insulin signaling cascade (including GSK3) and gene expression in the liver and the muscle in order to evaluate the action of insulin in fed chickens.

\section{Materials and Methods}

\section{Experimental protocol}

One-day-old male broiler chickens ( $n=75$, ISA 915, Institut de Sélection Animale, Saint Brieuc, France) were housed in an environment-controlled room in individual wire cages equipped with individual feeders and water bowls. They were fed a conventional balanced diet ad libitum and after 2 days of age, exposed to a $14 \mathrm{~h}$-light period per day (0600-2000 h). Diet $(3050 \mathrm{kCal}$ or $12.8 \mathrm{~mJ} / \mathrm{kg}$, metabolizable energy, $22 \%$ proteins (Nx6.25)) were based on corn, wheat, peas, soyabean meal, corn gluten, and rapeseed oil. Body weight was measured at $1,8,12$, and 14 days to minimize handling stress and individualize five groups of seven chickens exhibiting similar body weights (BW) at 16 or 17 days of age. The fed control group received three i.v. injections delivering normal guinea pig serum (PromoCell, Heidelberg, Germany; $1.5 \mathrm{ml} / \mathrm{kg}$ each) at time 0,2 , and $4 \mathrm{~h}$ (abbreviated as $5 \mathrm{hrfed}-\mathrm{C}$ group, $\mathrm{BW}=475 \pm 18 \mathrm{~g}, n=7)$. Another fed group received three i.v. injections delivering anti-porcine insulin guinea pig serum $(1.5 \mathrm{ml} / \mathrm{kg}$ ) at 0,2 , and $4 \mathrm{~h}$ (abbreviated as $5 \mathrm{hrfed}-\mathrm{Ab}$ group, $\mathrm{BW}=500 \pm 22 \mathrm{~g}, n=7)$. Immune sera were prepared as described earlier (Simon et al. 2000). Two additional treatment groups, maintained on feed, received one single i.v. injection $(1.5 \mathrm{ml} / \mathrm{kg})$ at $4 \mathrm{~h}$ of either normal guinea pig serum (abbreviated as 1 hrfed-C group, BW $=505 \pm 21 \mathrm{~g}, n=7$ ) or anti-porcine insulin guinea pig serum (abbreviated as $1 \mathrm{hrfed}-$ $\mathrm{Ab}$ group, $\mathrm{BW}=496 \pm 17 \mathrm{~g}, n=7)$. The last group, which served as an additional control to measure the extent of changes induced by insulin immuno-neutralization, was fasted for $5 \mathrm{~h}$ and given three i.v. injections of normal guinea pig serum $(1.5 \mathrm{ml} / \mathrm{kg})$ at time 0,2 , and $4 \mathrm{~h}$ (abbreviated as 5 hrfasted-C group, $\mathrm{BW}=471 \pm 18 \mathrm{~g}, n=7$ ). In a preliminary assay, it was checked that the anti-insulin antibody mixture had a hyperglycemic effect (and not an insulin mimetic effect). Food intake was measured after $1 \mathrm{~h}$ for $1 \mathrm{hrfed}-\mathrm{C}$ and $1 \mathrm{hrfed}-\mathrm{Ab}$ groups or 5 -h insulin immuno-neutralization for 5 hrfed-C and 5 hrfed-Ab groups. After blood sampling under EDTA, the chickens were killed by cervical dislocation. Liver and leg muscle samples were quickly removed, frozen in liquid nitrogen, and stored at $-80^{\circ} \mathrm{C}$ until analysis. After blood centrifugation, aliquots of plasma were prepared and stored at $-20{ }^{\circ} \mathrm{C}$ until analysis. All procedures described herein were approved by the Agricultural Agency and the Scientific Research Agency and conducted in accordance with the guidelines for Care and Use of Agricultural Animals in Agricultural Research and Teaching.

\section{Metabolic and hormone analyses}

Plasma glucose levels were measured by the glucose oxidase method (Glucose Beckman Analyser 2, Beckman, Palo Alto, CA, USA). Free or non-esterified fatty acid (NEFA) levels were determined with an enzymatic colorimetric kit (Wako Chemicals, Neuss, Germany). Plasma $\alpha$ NH2NPN concentrations ( $\alpha$-amino-non-protein nitrogen, an estimate of total free amino acids) were measured after extraction with $10 \%$ $(\mathrm{v} / \mathrm{v})$ sulfosalicylic acid, using the $2 \%$ ninhydrin reagent (Sigma Chemicals) and L-serine as standard. Plasma glucagon levels were determined by RIA with a specific C-terminal pancreatic glucagon antibody, which does not cross-react with gut glucagon (Ruffier et al. 1998), a generous gift from Leclercq-Meyer, and porcine glucagon (Elli Lilly France) as the standard. Plasma tri-iodothyronine $\left(\mathrm{T}_{3}\right)$ concentrations were estimated by specific RIA using a commercial coated tube kit (Coat-A-Count, Diagnostic Product Corporation France, La Garenne Colombes, France). The RIA appeared not sensitive enough to get reliable plasma thyroxine $\left(T_{4}\right)$ concentrations using the present samples. For each hormone, all samples were measured in one RIA.

\section{Preparation of tissue extracts}

For analyzing insulin signaling components, the liver and leg muscle soluble protein lysates were prepared as described 
previously (Dupont et al. 1998a,b). Protein content of extracts was determined using the BCA kit (Interchim, Montluçon, France). For preparing liver membranes and nuclear extracts, liver samples were homogenized in buffer 1 (10 mM HEPES, $\mathrm{pH}$ 7.9, $10 \mathrm{mM} \mathrm{KCl}, 1.5 \mathrm{mM} \mathrm{MgCl}_{2}, 1 \mathrm{mM}$ EDTA, $1 \mathrm{mM}$ EGTA, $1 \mathrm{mM}$ dithiothreitol). Homogenates were centrifuged at $1100 \mathrm{~g}$ for $10 \mathrm{~min}$. Resulting nuclear pellets were washed once in buffer 1 and then re-suspended in buffer $2(20 \mathrm{mM}$ HEPES, pH 7.9, $420 \mathrm{mM} \mathrm{NaCl}, 25 \%$ (v/v) glycerol, $1.5 \mathrm{mM}$ $\mathrm{MgCl}_{2}, 1 \mathrm{mM}$ EDTA, $1 \mathrm{mM}$ EGTA, $1 \mathrm{mM}$ dithiothreitol). This suspension was rotated for $30 \mathrm{~min}$ and then centrifuged at $15000 \boldsymbol{g}$ for $30 \mathrm{~min}$. The resulting supernatant was designated as the nuclear extract fraction. The membrane extract fraction was prepared by centrifuging the supernatant of the original $1100 \mathrm{~g}$ spin for $1 \mathrm{~h}$ at $100000 \mathrm{~g}$. The resulting membrane pellet was dissolved in buffer $3(10 \mathrm{mM}$ Tris, $\mathrm{pH}$ 6.8, $100 \mathrm{mM} \mathrm{NaCl}, 1 \%(\mathrm{w} / \mathrm{v})$ SDS, $1 \mathrm{mM}$ EDTA, $1 \mathrm{mM}$ EGTA, $1 \mathrm{mM}$ dithiothreitol).

\section{Western blotting and PI3K activity}

Tissue extracts were subjected to electrophoresis on $10 \%$ (w/v) SDS-polyacrylamide gels under reducing conditions and electro-transferred as described previously (Dupont et al. 1998a). Membranes were then incubated overnight at $4{ }^{\circ} \mathrm{C}$ with appropriate antibodies: p-ERK1/2 (T202/Y204), p-Akt (S473), Akt, p-GSK3- $\beta$ (S9), p-P70S6K1 (T389), p-P70S6K1 (T421/S424), and p-S6 (S235/236) (Cell Signaling, Beverly, MA, USA); Shc and phosphotyrosine (PY20) (Biosciences, Le Pont de Claix, France); ERK2, P70S6K1, and GK (Santa Cruz Biotechnology, Santa Cruz, CA, USA); Vinculin (Sigma Chemicals); IRS-1, Shc $66 \mathrm{kDa}$, and p85 (Upstate Biotechnology Inc., Lake, Placid, NY, USA); and SREBP1 (Abcam, Paris, France). Anti-IR (B10) was a generous gift from Dr P. Gorden (National Institute of Diabetes and Digestive and Kidney Diseases, Bethesda, MD, USA). The signal was detected by enhanced chemiluminescence (ECL, GE Healthcare Europe GmbH, Saclay, France). The films were analyzed and signals quantified with the software MacBas V2.52 (Fuji PhotoFilm, USA, Inc.). Commercial antibodies directed against mammalian proteins used in western blot experiments have been previously shown to cross-react with chicken homolog protein at a good extent (confirming description of species specificity by trade companies, when available, see references from Dupont et al. and Tesseraud et al. quoted herein). insulin-like growth factor1 (IGF1) blotting was performed as described previously (Beccavin et al. 1999) and IGF binding protein 1 band $(28 \mathrm{kDa})$ was quantified using the PhosphoImager (Storm 840, GE Healthcare Europe $\mathrm{GmbH}$, Saclay, France). PI3K activity was measured in p85 immuno-precipitates from liver and leg muscle homogenates (2 mg protein) using an anti-rat p85 subunit antibody (Upstate Biotechnology Inc, Euromedex, France) and protein $\mathrm{G}$ agarose beads (GE Healthcare Europe $\mathrm{GmbH}$ ) as described previously (Dupont et al. 1998a).

\section{$R N A$ isolation and $q R T-P C R$ analyses}

After tissue powdering under liquid nitrogen, total RNA was extracted using RNeasy Mini or Midi kits (Qiagen). After RNase-free DNase treatment, RNA was reverse transcribed using random hexamers and SuperScriptII reverse transcriptase. Quantitative real-time PCRs (qRT-PCR) were performed in duplicate using an ABI Prism 7000 Sequence Detection System (Applied Biosystems, Foster City, CA, USA) (Pfaff 2001). The sequences of primers (specifically designed or reproduced from the literature) are shown in Table 1. PCR product sequences were checked. For each gene assay, experimental and reference samples were measured in one 96-well plate. Results were expressed as $\Delta \mathrm{ct}(\Delta \mathrm{ct}=$ reference pool $\mathrm{ct}-$ sample $\mathrm{ct})$; when negative, gene expression was lower in the sample than in the reference pool and the reverse when positive. Composition of the reference RNA pool is indicated in the footnotes to Table 3.

\section{Statistical analysis}

Data are presented as means \pm s.E.M. Data were analyzed by ANOVA and treatment means were compared by Fisher's test or $t$-test, significance was set at $P<0 \cdot 05$.

\section{Results}

\section{Metabolic parameters}

Cumulative food intake (Table 2) was decreased at $1 \mathrm{~h}$ after a single anti-insulin serum injection (1hrfed-Ab versus 1 hrfedC) or at $5 \mathrm{~h}$ after three anti-insulin serum injections (5hrfed$\mathrm{Ab}$ versus 5 hrfed-C). Plasma glucose concentration was not significantly altered by food privation for $5 \mathrm{~h}$ (5hrfasted-C), whereas large hyperglycemia was induced by anti-insulin serum injection in the 1 hrfed-Ab and 5 hrfed-Ab groups when compared with their respective fed controls. Striking hyperglycemia was also present at 2 and $4 \mathrm{~h}$ before the second and third injections (not shown). Plasma NEFA levels significantly increased in the 5hrfed-Ab group, though at a lower extent than in 5hrfasted-C group. Plasma levels of aNH2NPN also significantly increased in the 5hrfed-Ab group, whereas they decreased following fasting (5hrfasted-C). Plasma glucagon was increased following fasting (5hrfasted-C group) and insulin privation (5hrfed$\mathrm{Ab})$; it is noteworthy that these increases have been underestimated (see footnote to Table 2). Plasma $\mathrm{T}_{3}$ was decreased after 5-h fasting (5hrfasted-C) and after 1 - or 5-h insulin privation (1hrfed-Ab or 5 hrfed-Ab).

\section{IR signaling cascade}

In the liver, anti-insulin serum significantly decreased tyrosine phosphorylation levels of IR $\beta$-subunit, IRS-1 and Shc $52 \mathrm{kDa}$ isoform as well as PI3K activity at $1 \mathrm{~h}$ (1hrfed-Ab 
Table 1 Primers used for quantitative RT-PCR of messengers in liver and/or leg muscles

Forward primer $\left(5^{\prime}-3^{\prime}\right)$

Messengers
Ribosomal $18 \mathrm{~S}$
$\beta$-Actin
Transcription factors
Egr1
PPAR $\alpha$
PPAR $\beta$
PPAR $\gamma$
SREBP1
THRSP $\alpha$ (spot14)
PGC1 $\alpha$
Endocrine and signaling system
D1-Deiodinase
D2-Deiodinase
D3-Deiodinase
IGFBP1
Adiponectin
Adiponectin R1
Adiponectin R2
GSK3 $\beta$
Metabolism
GK
FASN
Cox4
avUCP
Atrogin-1
MURF1
Cathepsin B

Taqman control kit

CTGGCACCTAGCACAATGAA

GAGCATCTTGCGGCAGACA

CAAACCAACCATCCTGACGAT

CATGGAGCCCAAGTTTGAGT

CACTGCAGGAACAGAACAAAGAA

GTCGGCGATCCTGAGGAA

TTCTCGGCCACGCAGAAG

GGGACCGGTTTGAAGTTTTTG

TTTCAGCTTCCAGTATTTGCTCTTT AGAAGCTCCGAACTCCAGTGTAA GGAAATCGTGTCTGATGTTGTCA CTATTTGCCCAACTGTAACAAG GCCAGGTCTACAAGGTGTCA CCAGGAGAAGGTTGTGTTTG TCATGGCTCTTCCACACAGT AGCTGTTCCGGAGTTTAGCCTAT

TGGTGCTGCTGCGGCTGGTGGA TCTCGATCTGGCATACGAACTG CTTTCCACCTCCATCTGTGTGA CTACGACCTCATCAAGGACACA GACGCGCTTTCTCGATGAG TGTCTATGGGCTGCAGAGGAA CAAGCTCAACACCACTGGAA
Reverse primer $\left(5^{\prime}-3^{\prime}\right)$

Taqman control kit CTGCTTGCTGATCCACATCT

AGGCTCTGGCCATAAGGTGTT GGAGGTCAGCCATTTTTTGGA CGGAGGATGTTGTCTTGGAT TCCACAGAGCGAAACTGACATC CTCTTCTGCACGGCCATCTT AAGACCCCTCGCAGCAGG GGCTCGTTTGACCTGCGTAA

\author{
GTCCCTCGTGGGCTTCGT \\ CCCCGGCTCCTTCAAAA \\ AACCCCССССATAAATAGGA \\ CAGCACCCAGCGGAATCT \\ CCATGTGTCCTGGAAATCCT \\ TGATCAGCAGTGCAATTCCT \\ AAGGCTGAGGGTTGCAGTAG \\ ACGTTAGGTTCTCCACGAACCA
}

GTTGTAGATCTGCTTGCGGTCTCCT
CAACTGGCTCGAGCTTCAAAG
TGCTGGATGGCTGAAATCG
GAAGGCAGCCACGAAGTGA
CCTTGTTATTCAGTAGGTCTTTTTCCT
GGTGCTCCCCCTTCTTGAGT
TCAAAGGTATCCGGCAAATC

versus 1 hrfed-C, Fig. 1A-D). The extent of these decreases is quite similar to that induced by 5 -h fasting (5hrfasted-C versus 1 hrfed-C). In the chicken tissues, Shc $52 \mathrm{kDa}$ is the main isoform tyrosine phosphorylated in response to insulin (Dupont et al. 1998b). Phosphorylations of Akt, GSK3 $\beta$, ERK2, and the S6 ribosomal protein were accordingly inhibited in both conditions (Fig. 1E-I). In chicken, only ERK2 form is phosphorylated (Duchêne et al. 2008a,b). For a yet unknown reason, stimulation of phosphorylation of
P70S6K1 and activation of S6K (using specific artificial substrate) by insulin are not detectable in the liver, though insulin stimulation of phosphorylation of S6 ribosomal protein is observed in the same conditions (Duchêne et al. $2008 a$ ). In the muscle, in contrast to what was observed in the liver, injection of anti-insulin serum (1hrfed-Ab) or food deprivation for $5 \mathrm{~h}$ (5hrfasted-C) did not alter tyrosine phosphorylation levels of the IR- $\beta$ subunit and IRS-1 (versus 1hrfed-C, Fig. 2A and B) or PI3K activity (Fig. 2D). Both

Table 2 Food intake and plasma metabolite and hormone parameters*

\begin{tabular}{|c|c|c|c|c|c|c|}
\hline & 1hrfed-C & 5hrfed-C & 1hrfed-Ab & 5hrfed-Ab & 5hrfasted-C & $P$ level \\
\hline \multicolumn{7}{|l|}{ Group } \\
\hline Food intake, $g$ & $4 \cdot 3 \pm 0 \cdot 3^{a}$ & $18 \cdot 4 \pm 0 \cdot 7^{\mathrm{A}}$ & $2 \cdot 4 \pm 0 \cdot 4^{b}$ & $14 \cdot 0 \pm 0 \cdot 6^{\mathrm{B}}$ & & \\
\hline NEFA, mg/100 ml & $7 \cdot 6 \pm 0 \cdot 3^{c}$ & $7 \cdot 3 \pm 0 \cdot 3^{c}$ & $9 \cdot 6 \pm 0 \cdot 6^{b c}$ & $11 \cdot 6 \pm 0 \cdot 6^{b}$ & $19 \cdot 7 \pm 1 \cdot 7^{\mathrm{a}}$ & $0 \cdot 0001$ \\
\hline$\alpha \mathrm{NH} 2 \mathrm{NPN}, \mathrm{mg} / 100 \mathrm{ml}$ & $93 \pm 4^{b}$ & $92 \pm 6^{b}$ & $106 \pm 5^{b}$ & $161 \pm 10^{a}$ & $65 \pm \overline{5^{c}}$ & $0 \cdot 0001$ \\
\hline Glucagon, ng/ml & $0 \cdot 1 \overline{2} \pm 0 \cdot 05^{b}$ & $0 \cdot 0 \overline{5} \pm 0 \cdot 02^{\mathrm{c}}$ & $\left(0 \cdot 39 \pm 0 \cdot 20^{b}\right)$ & $\left(1 \cdot 08 \pm 0 \cdot 18^{a}\right)$ & $\left(0 \cdot \overline{89} \pm 0 \cdot 19^{a}\right)$ & $0 \cdot 0001$ \\
\hline $\mathrm{T}_{3}, \mathrm{ng} / \mathrm{ml}$ & $2 \cdot 49 \pm 0 \cdot 23^{\mathrm{a}}$ & $2 \cdot 19 \pm 0 \cdot 20^{\mathrm{a}, \mathrm{b}}$ & $1 \cdot 97 \pm 0 \cdot 16^{b}$ & $1 \cdot 06 \pm 0 \cdot 12^{\mathrm{c}}$ & $0 \cdot 64 \pm 0 \cdot 08^{\mathrm{c}}$ & $0 \cdot 0001$ \\
\hline
\end{tabular}

*Food intake was 1 -h cumulative intake for $1 \mathrm{hrfed-C}$ and $1 \mathrm{hrfed-Ab}$ groups following one normal serum injection or one anti-insulin serum injection respectively, and 5 -h cumulative food intake for 5 hrfed-C and 5 hrfed-Ab groups following three injections of respective serum. Data are mean \pm s.E.M., $n=7$. For food intake, statistical analysis has been performed using two $t$-test comparing data at 1 or $5 \mathrm{~h}$ respectively; differences were significant at $1 \mathrm{~h}(P<0 \cdot 008$, a versus b) and $5 \mathrm{~h}(P<0 \cdot 0001, \mathrm{~A}$ versus $\mathrm{B})$. For plasma parameters, statistical analyses were performed including all experimental groups $\left(F_{4,30}\right) ;$ values possessing different superscripts in the same row are significantly different $(P<0 \cdot 05)$. Free fatty acids (NEFA) are expressed as mg equivalent oleic acid/100 ml. $\alpha \mathrm{NH} 2 \mathrm{NPN}$ $(\alpha \mathrm{NH} 2$ non-protein nitrogen) is expressed as $\mathrm{mg}$ L-serine equivalent/100 ml. Glucagon mean values from the $1 \mathrm{hrfed}-\mathrm{Ab}$, $5 \mathrm{hrfed}-\mathrm{Ab}$, and $5 \mathrm{hrfasted}-\mathrm{C}$ groups are indicated in parenthesis to mean that these values are underestimated; one value in the $1 \mathrm{hrfed-Ab}$, two values in the $5 \mathrm{hrfed}-\mathrm{Ab}$ group, and two values in the 5 hrfasted-C group were out of range and replaced by $1.5 \mathrm{ng} / \mathrm{ml}$, i.e. the maximum reliable value in the assay. Paucity of plasma did not permit further measurements at lower plasma concentrations. 
Liver

1hrfed-C

1hrfed-Ab

5hrfasted-C

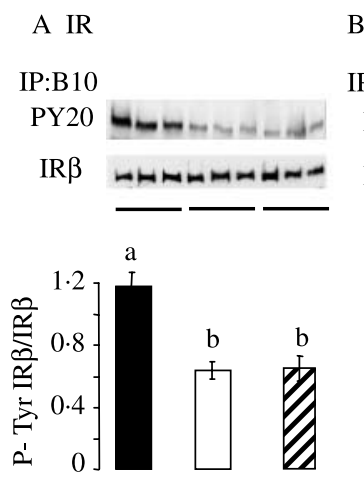

B IRS-1

C Shc

D PI3'-kinase activity

IP:IRS-1

PY20

IRS-1

$4 \sin$
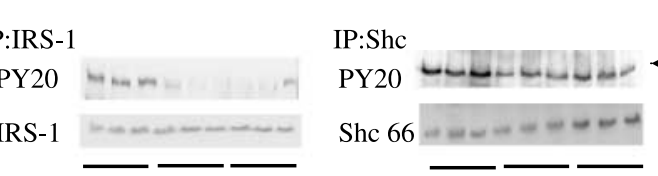

$\mathrm{kDa}$

52 IP:P85
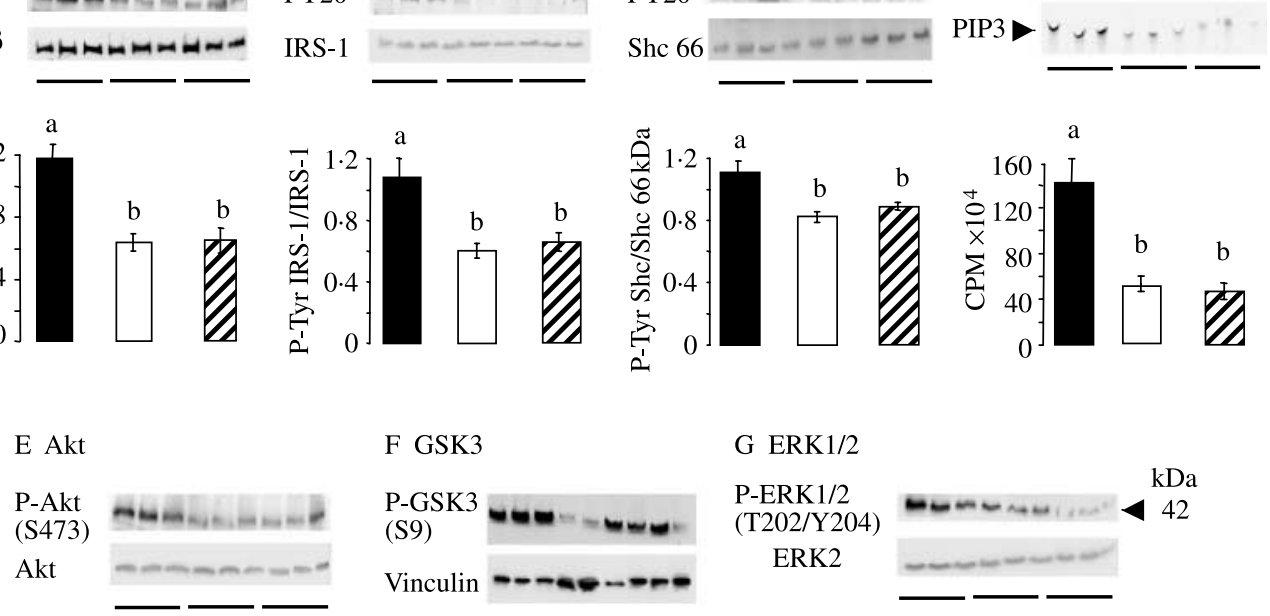

F GSK3

G ERK1/2
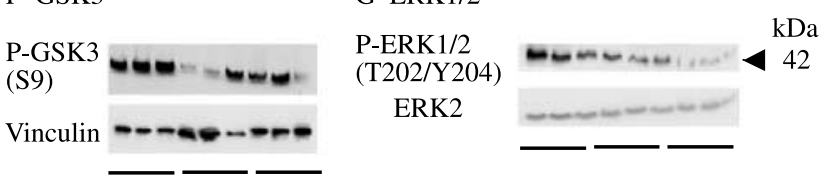

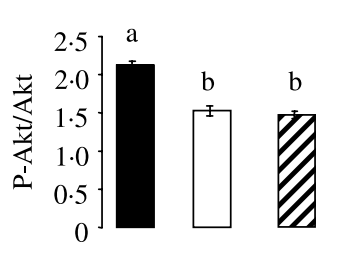

H P70S6K1

P-S6K1

(T389)

Undetectable phosphorylation levels
P-S6K1

(T421/424)
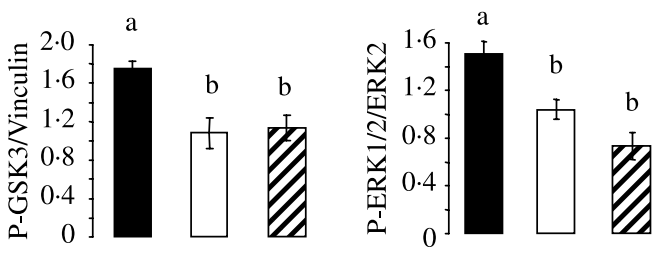

Undetectable phosphorylation levels
I S6 ribosomal protein

P-S6

(S235
/236)

Vinculin
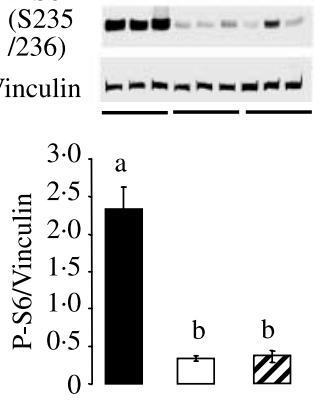

Figure 1 Insulin signaling in chicken liver $1 \mathrm{~h}$ after one anti-insulin serum injection. It shows western blots ((A) phospho-IR $\beta$, (B) IRS-1, and (C) Shc $52 \mathrm{kDa}$ on tyrosine residues and (E) phospho-Akt, (F) GSK3 $\beta,(\mathrm{G})$ ERK2, (H) p70S6 kinase, and (I) S6 ribosomal protein)) and (D) PI3K activities in liver lysates of fed chickens injected with either normal serum ( $1 \mathrm{hrfed}-\mathrm{C}$ ) or anti-insulin serum (1 hrfed-Ab). As an additional control, one group of chicken fasted for $5 \mathrm{~h}$ received three injections of normal serum ( 5 hrfasted-C). In western blots, when immuno-precipitations (IP) had been performed before gel electrophoresis, the antibody used is indicated as: IP:xxx; immune sera used to reveal protein phosphorylation levels are indicated to the left of gels (for instance, PY20 is directed against anti-phosphotyrosine residues). The levels of phosphorylation of IR, IRS1, Akt, and ERK2 have been normalized by the level of the corresponding protein using specific antibodies indicated to the left of gels. For $\mathrm{Shc}$, the phosphorylation of $52 \mathrm{kDa}$ isoform (the main tyrosine phosphorylated Shc isoform in response to insulin) has been normalized by the level of $66 \mathrm{kDa}$ isoform. Phosphorylation levels of GSK3 $\beta$ and S6 ribosomal protein have been normalized by the level of vinculin. In chicken tissues, only ERK2 is phosphorylated. For each protein, gels show bands, which have been underlined per group with three chickens per group. From the left to the right, groups are $1 \mathrm{hrfed}-\mathrm{C}, 1 \mathrm{hrfed}-\mathrm{Ab}$, and 5 hrfasted-C groups. Below each gel, histograms represent mean \pm s.E.M. from two gels, with $n=6$ /group (the legend for groups is on top of the figure). When letters above bars differ, means significantly differ by at least $P<0 \cdot 05$. 
Muscle

1hrfed-C

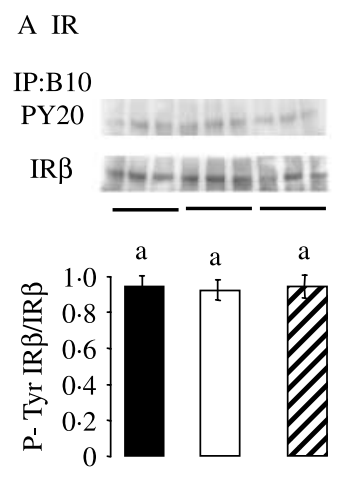

B IRS-1

IP:IRS-1

PY20 - - - - - -
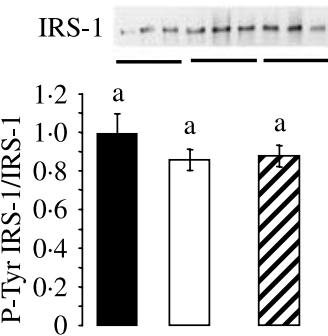

1hrfed-Ab

C Shc

IP:Shc

PY20

Shc 66

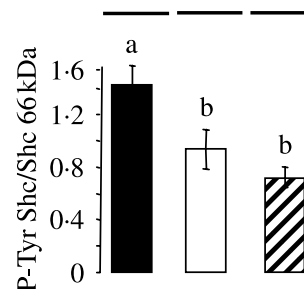

5hrfasted-C

D PI3'-kinase activity

$\mathrm{kDa}$

52

IP:P85

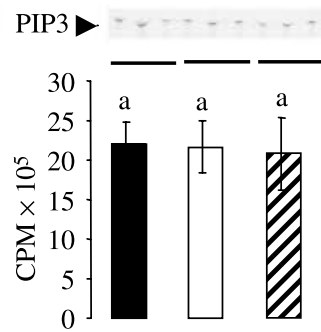

E Akt

P-Akt

(S473)

Akt

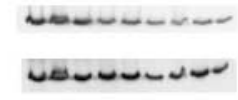

F GSK3

G ERK1/2
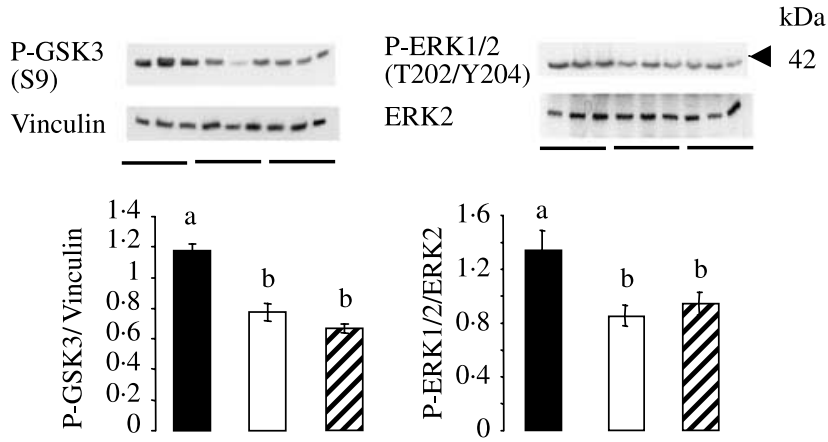

H P70S6K1

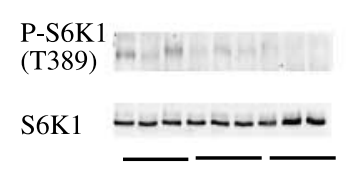

P-S6K1

(T421/

ตำยะ

I S6 ribosomal protein

P-S6

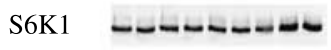

(S235/236)

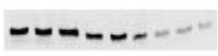

Vinculin _-n-
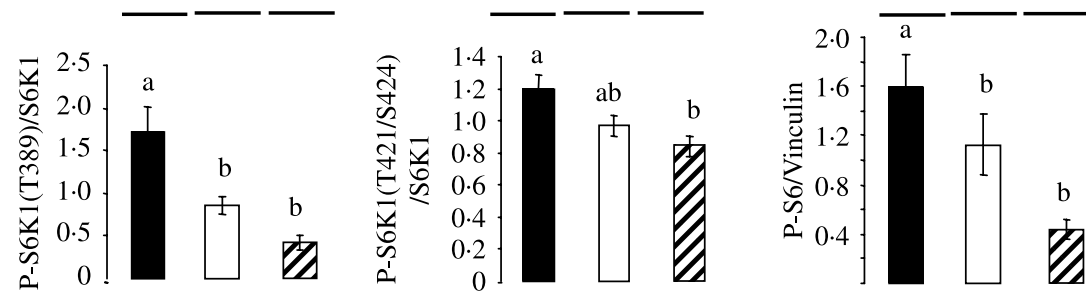

Figure 2 Insulin signaling in chicken leg muscles $1 \mathrm{~h}$ after one anti-insulin serum injection. It shows western blots ((A) phospho-IR $\beta$, (B) IRS-1, and (C) Shc 52 kDa on tyrosine residues and (E) phospho-Akt, (F) GSK3 $\beta$, (G) ERK2, (H) p70S6 kinase, and (I) S6 ribosomal protein)) and (D) PI3K activities in leg muscle lysates of fed chickens injected with either normal serum (1 hrfed-C) or anti-insulin serum (1 hrfed-Ab). As an additional control, one group of chicken fasted for $5 \mathrm{~h}$ received three injections of normal serum (5hrfasted-C). In western blots, antibodies used for immuno-precipitations (IP), measurements of phosphorylations and normalizations were the same as indicated in the legend to Fig. 1. Phosphorylation of T389 and T421/424 residues of P70-S6 kinase has been measured using specific antibodies indicated to the left of gels. For each protein, gels show bands, which have been underlined per group with three chickens per group. From the left to the right, groups are 1 hrfed-C, 1 hrfed-Ab, and 5 hrfasted-C groups. Below each gel, histograms represent mean \pm s.E.M., from two gels with $n=6 /$ group (the legend for groups is on top of the figure). When letters above bars differ, means significantly differ by at least $P<0 \cdot 05$. 
conditions, however, decreased tyrosine phosphorylation of the Shc $52 \mathrm{kDa}$ protein (Fig. 2C). In addition, phosphorylations of Akt, GSK3 3 , ERK2, P70S6K1, and S6 were all decreased by insulin privation or 5 -h fasting (Fig. 2E-I). In both liver and muscle, AMPK phosphorylation on T172 residue in the $\alpha$ isoform was unaltered by any of the present experimental conditions, meaning that AMPK was not activated (data not shown).

\section{Effects of insulin privation on gene expression and protein levels}

We next investigated whether insulin privation could alter expression of some specific genes in the liver and the muscle of fed chickens. Genes were chosen as insulin sensitive in mammals and, for some, as potentially invariant. Selected genes are involved in transcription, endocrine systems, and metabolism. Quantitative RT-PCR was performed at $5 \mathrm{~h}$, comparing three conditions (5hrfed-Ab, 5hrfed-C, and 5 hrfasted-C). In the liver (Table 3 ), $18 \mathrm{~S}$ and $\beta$-actin mRNA were found invariant in the three experimental conditions. Expression of Egr1 was significantly reduced by anti-insulin serum but not by fasting. Expression of three transcription factors (PPAR $\gamma$, SREBP1, and THRSP $\alpha$ ) was significantly decreased by anti-insulin serum or fasting. Both anti-insulin serum and fasting also decreased the expression of D2-deiodinase, glucokinase (GK), and the fatty acid synthase (FASN) genes, whereas these two conditions increased the abundance of D3-deiodinase and IGFBP1 mRNA. In contrast, several other mRNA (PPAR $\alpha$, PPAR $\beta \delta$, adiponectin, adiponectin receptor R2, D1-deiodinase, and Cox4) were not significantly modified by either treatment (data not shown). In the muscle, only 6 out of the 20 genes studied were altered by anti-insulin antibodies, fasting, or both conditions (Table 4). The mRNA for PPAR $\beta \delta$ and atrogin1 were increased by anti-insulin serum or fasting. Gene expression for avUCP and MURF1 were increased, only by fasting. The expression of D3-deiodinase gene was also significantly decreased by fasting. The Egr1 mRNA level was selectively decreased by anti-insulin antibodies. Expression of several other genes (18S, $\beta$-actin, PGC1 $\alpha$, PPAR $\alpha, \operatorname{PPAR} \gamma$, SREBP1, THRSP $\alpha$, D2-deiodinase, adiponectin, adiponectin receptor R1, GSK3 $\beta$, Cox4, and cathepsin B) were not altered.

Finally, the levels of some proteins have been assessed. Liver GK and SREBP1 protein decreased at $5 \mathrm{~h}$ following insulin privation or fasting (Fig. 3A and B). The plasma IGFBP1 protein increased following insulin privation or fasting (5hfed-Ab or 5hrfasted-C, Fig. 3C).

\section{Discussion}

Privation of insulin by immuno-neutralization rapidly induced large hyperglycemia in fed chickens. Lipid and amino acid metabolism was also disturbed. The increase in plasma NEFA most likely resulted from the development of an early hyper-glucagonemia (glucagon is the lipolytic hormone in birds while no anti-lipolytic effect has been demonstrated for insulin in chicken adipocytes (see references in (Simon 1989))). The fact that glucose requires the presence of insulin to inhibit pancreatic glucagon release has been previously recognized in ducks first, and then in mammals (Miahle's group references in Simon 1989). The increase in total plasma amino acids following insulin privation may have

Table 3 Liver genes altered at $5 \mathrm{~h}$ by insulin antibody or fasting $(\Delta \mathrm{ct})^{*}$

\section{5hrfed-C \\ 5hrfed-Ab}

Gene name

Transcription factors

$\begin{array}{lr}\text { Egr1 } & -2 \cdot 4^{\mathrm{a}} \pm 0 \cdot 2 \\ \text { PPAR } \gamma & 0 \cdot 15^{\mathrm{a}} \pm 0 \cdot 2 \\ \text { SREBP1 } & -0 \cdot 4^{\mathrm{a}} \pm 0 \cdot 3 \\ \text { THRSP } \alpha & 1 \cdot 2^{\mathrm{a}} \pm 0 \cdot 2 \\ \text { Endocrine system } & \\ \text { D2-Deiodinase } & 1 \cdot 3^{\mathrm{a}} \pm 0 \cdot 3 \\ \text { D3-Deiodinase } & -1 \cdot 5^{\mathrm{c}} \pm 0 \cdot 6 \\ \text { IGFBP1 } & -1 \cdot 3^{\mathrm{b}} \pm 0 \cdot 2 \\ \text { Metabolism } & \\ \text { GK } & 0 \cdot 72^{\mathrm{a}} \pm 0 \cdot 29 \\ \text { FASN } & 0 \cdot 2^{\mathrm{a}} \pm 0 \cdot 3\end{array}$

5hrfasted-C

$\begin{array}{cl}-2 \cdot 9^{\mathrm{a}} \pm 0 \cdot 2 & 0 \cdot 0002 \\ -0 \cdot 7^{\mathrm{b}} \pm 0 \cdot 3 & 0 \cdot 03 \\ -1 \cdot 8^{\mathrm{b}} \pm 0 \cdot 3 & 0 \cdot 05 \\ -1 \cdot 4^{\mathrm{b}} \pm 0 \cdot 2 & 0 \cdot 0005 \\ -3 \cdot 4^{\mathrm{b}} \pm 0 \cdot 6 & \\ 3 \cdot 1^{\mathrm{a}} \pm 0 \cdot 7 & 0 \cdot 001 \\ 3 \cdot 0^{\mathrm{a}} \pm 0 \cdot 8 & 0 \cdot 001 \\ & 0 \cdot 0001 \\ -0 \cdot 24^{\mathrm{b}} \pm 0 \cdot 06 & \\ -2 \cdot 3^{\mathrm{b}} \pm 0 \cdot 3 & 0 \cdot 01\end{array}$

*mRNA levels were determined by qRT-PCR analysis using primers listed in Table 1. A RNA pool was prepared from 15 aliquots of 10 micrograms issued from one chicken from each of the five experimental groups and three tissues: liver, leg, and breast muscles and used as a reference standard. Data were calculated as $\Delta \mathrm{ct}(\Delta \mathrm{ct}=\mathrm{RNA}$ reference pool ct - sample ct) for each messenger assayed at 1/100 dilution, except for: $18 \mathrm{~S}$ and $\beta$-actin (assayed at 1/5000 dilution) and GK (assayed at $1 / 8$ dilution). When $\Delta \mathrm{ct}$ is negative, messenger is less expressed in the sample than in the pool reference and the reverse is true when $\Delta \mathrm{ct}$ is positive (so, the higher $\Delta$ ct value is, the higher the mRNA abundance is). Data are presented as mean \pm s.E.M. for $n=7$. ANOVA significance $P$ levels are indicated in the last column to the right. One bird from the 5 hrfed-Ab group exhibited expression level largely out of range of this group for several genes. For PPAR $\gamma$ transcript, the value of this chicken $(\Delta c t=+0 \cdot 69)$ was excluded from the analyses. For this reason, the mean for $n=6$ is indicated in parenthesis. For each gene mRNA, means possessing different superscripts are significantly different. Several mRNAs were not significantly altered in the liver by the experimental treatments: ribosomal 18S, $\beta$-Actin, PPAR $\alpha$, PPAR $\beta \delta$, adiponectin, adiponectin R2, D1-deiodinase, and Cox4. 
Table 4 Leg muscle genes altered at $5 \mathrm{~h}$ by insulin antibody or fasting $(\Delta \mathrm{ct})^{*}$

\begin{tabular}{|c|c|c|c|c|}
\hline & 5hrfed-C & 5hrfed-Ab & 5hrfasted-C & $P$ level, ANOVA \\
\hline \multicolumn{5}{|c|}{ Transcription factors } \\
\hline PPAR $\beta \delta$ & $-0 \cdot 5^{\mathrm{b}} \pm 0 \cdot 1$ & $0 \cdot 3^{\mathrm{a}} \pm 0 \cdot 2$ & $0 \cdot 5^{\mathrm{a}} \pm 0 \cdot 1$ & $0 \cdot 002$ \\
\hline \multicolumn{5}{|l|}{ Endocrine system } \\
\hline D3-Deiodinase & $-1 \cdot 3^{a} \pm 0 \cdot 4$ & $-1 \cdot 5^{a} \pm 0 \cdot 2$ & $-2 \cdot 4^{b} \pm 0 \cdot 2$ & $0 \cdot 04$ \\
\hline \multicolumn{5}{|l|}{ Metabolism } \\
\hline MURF1 & $-0 \cdot 4^{\mathrm{b}} \pm 0 \cdot 3$ & $0 \cdot 1^{\mathrm{b}} \pm 0 \cdot 2$ & $1 \cdot 6^{\mathrm{a}} \pm 0 \cdot 3$ & $0 \cdot 0001$ \\
\hline
\end{tabular}

*Expression levels were determined by qRT-PCR analysis using primers listed in Table 1 and the RNA reference pool described in Table 3. Data were calculated as $\Delta \mathrm{ct}(\Delta \mathrm{ct}=$ pool reference $\mathrm{ct}-$ sample $\mathrm{ct})$ for each mRNA assayed at 1/100 dilution, except for $18 \mathrm{~S}$ and $\beta$-actin messengers which were assayed at $1 / 5000$ dilution. When $\Delta \mathrm{ct}$ is negative, mRNA levels are lower in the sample than in the pool reference and the reverse is true when $\Delta \mathrm{ct}$ was positive (so, the higher $\Delta \mathrm{ct}$ value is, the higher the mRNA abundance is). Data are presented as mean \pm s.E.M. for $n=7$. ANOVA P levels of significance are indicated in the last column to the right. For each gene mRNA, means possessing different superscripts are significantly different. Several transcripts were not significantly altered by treatments: $18 \mathrm{~S}$, PGC1 $\alpha$, PPAR $\alpha$, PPAR $\gamma$, SREBP1, THRSP $\alpha$, D2-deiodinase, adiponectin, adiponectin R1, GSK3 $\beta$, Cox4, and cathepsin B.

multiple origins: changes in amino acid uptake, protein synthesis, and/or protein degradation since all these components are insulin dependent, including in chicken (Simon 1989, Tesseraud et al. 2007b). A rapid decrease in food intake was the last general perturbation observed, which suggests that glucose and insulin interact in a complex manner to balance orexigenic and anorexigenic pathways in the brain and/or at the peripheral tissues. Such impairment in food intake had not been previously observed most likely because hyperglycemia was not so high in comparison with the present results (Simon et al. 2000). One possible hypothesis could be that in the present conditions, cerebrospinal fluid concentration of insulin had not yet changed whereas that of glucose increased, leading to a satiety signal. In order to get some insight into the mechanisms involved into the development of such acute 'diabetic' status, the insulin signaling pathways and the expression of some specific genes have been assessed in the liver and the muscle.

In the chicken liver, the main steps of the insulin signaling cascade are, accordingly, dependent on the insulin status (Dupont et al. 1998b,c, 2004). In the present study, a fasting period as short as $5 \mathrm{~h}$ appeared sufficient to turn-off liver insulin signals. IR, IRS-1, and Shc tyrosine phosphorylation; PI3K activity; and phosphorylations of Akt, GSK3, ERK2, and S6 ribosomal protein were all strongly inhibited, clearly indicating the development of a catabolic status. These changes were large and very fast, which may result from high internal body temperature $\left(42^{\circ} \mathrm{C}\right)$ and turnover rate of chicken metabolism. Insulin privation in fed chicken also turned off all the same signaling components in the liver at $1 \mathrm{~h}$ to an extent similar to that induced by $5 \mathrm{~h}$ of fasting.

In contrast, in leg muscles, IR and IRS-1 tyrosine phosphorylation and PI3K activity were totally unresponsive to fasting or insulin privation. However, Shc $52 \mathrm{kDa}$ tyrosine phosphorylation, thr/ser phosphorylation of P70S6K1, and phosphorylation of the other proteins assessed in the liver, all decreased in both situations (5-h fasting and 1-h insulin privation). As previously observed (Dupont et al. 2004), high amounts of $\mathrm{p} 85$ subunit of PI3K and high activities of PI3K are constitutively present in chicken muscle when compared with rat muscle. In normal or diabetic mice, a decrease in the amount of PI3K does improve insulin sensitivity (Terauchi et al. 1999, Ueki et al. 2002). Recently, it has been shown that an excess of p 85 may impair insulin signaling by competing with binding of the active p85-p110 complex to IRS1 and activating two counter-regulatory enzymes: PTEN (lipid phosphatase and Tensin homolog) and c-Jun N-terminal kinase (JNK; Taniguchi et al. 2006a,b, 2007). The presence of high amounts of 85 subunit in chicken muscle may therefore contribute to the low sensitivity to exogenous insulin observed in chicken. Other surprising features for insulin signal cascade in chicken muscle were largely substantiated and extended in the present study. Namely, several components generally considered as downstream effectors of PI3K (Akt, GSK3 $\beta$, and P70S6K1) up to the subsequent phosphorylation of S6 ribosomal protein were inactivated by insulin privation in fed chickens (and $5 \mathrm{~h}$ fasting). Amino acids have been shown to activate P70S6K1 in vitro, mimicking insulin action (Tesseraud et al. 2007a). In the present conditions, following insulin privation, amino acid levels increased in plasma but were ineffective at supporting an active P70S6K1. The alteration observed for the phosphorylation of ERK 2 could be related to the decrease in Shc tyrosine phosphorylation. IRS-2, another important IR substrate in mammals, has not yet been characterized in chicken to our knowledge. An IRS-2 homolog coding sequence has been recently suggested in the chicken genome on chromosome 1 (Ensemble release 47, October 2007 at http://www.ensembl. org/Gallus_gallus/index.html). However, it is hard to conceive that Shc and/or another IRS would account for insulin action in chicken muscle, via the typical PI3K pathway described in mammals (White \& Kahn 1994). Glucagon receptors activate hydrolysis of phosphatidylinositol phosphates in addition to the activation of the major adenylate 

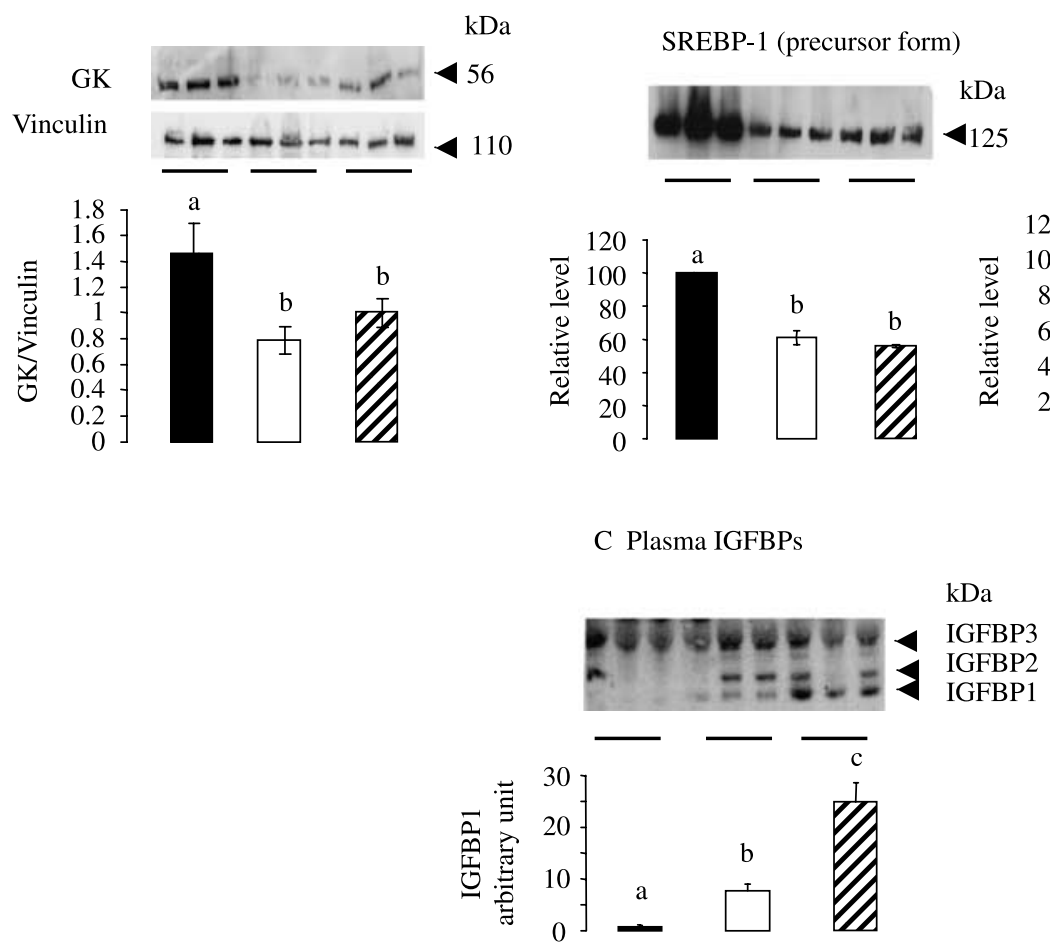

Figure 3 Effect of insulin privation or fasting for $5 \mathrm{~h}$ on liver or plasma proteins. Blots show (A) protein levels of liver GK (cytosol extracts), normalized by vinculin amount; (B) precursor and mature forms of liver SREBP1 (nuclei and membranes), normalized in comparison with 5hfed-C group; and (C) 125-I-IGF1 ligand blotting to plasma IGFBPs, expressed as arbitrary units. Fed chickens were i.v.-injected at time 0, 2, and $4 \mathrm{~h}$ with either normal ( $5 \mathrm{hfed}-\mathrm{C}$ ) or anti-insulin serum ( $5 \mathrm{hfed}-\mathrm{Ab}$ ). As an additional control, one group of chicken fasted for $5 \mathrm{~h}$ received three injections of normal serum ( 5 hrfasted-C). Experimental groups and results are shown in the same format as in Fig. 1 . IGF1 ligand blotting was performed as described in materials and methods, using plasma sample ( $8 \mu \mathrm{l} /$ chicken). Gels are from $n=3 \mathrm{chickens/group.} \mathrm{Below} \mathrm{each}$ gel, histograms represent mean \pm s.E.M. from two gels with $n=6$ /group (the legend for groups is on top of the figure).

cyclase/protein kinase A signaling pathway (Unson et al. 1989). No evidence of an alternative pathway has been clearly supported yet for insulin receptors. A unifying hypothesis would be that transient or discrete changes in IR tyrosine phosphorylation, undetectable with the present methodology may occur in vivo, which would account for small changes in Shc $52 \mathrm{kDa}$ tyrosine phosphorylation as presently and previously (Dupont et al. 2004) observed in chicken muscle. Within this hypothesis, Shc and potentially other IRS, but not IRS-1, would control signaling steps beyond the PI3K through an unknown and hypothetical bypass or parallel mechanism. This would enable insulin to exert some control in chicken muscle.

It is also noteworthy that AMPK has not been activated in the liver or the muscle by either $1-\mathrm{h}$ insulin privation or $5-\mathrm{h}$ fasting. AMPK, a serine-threonine kinase now considered as an energy sensor, is activated in response to nutrient deficiency or stress to support cellular metabolism and prevent a decrease in ATP cellular level (Long \& Zierat
2006). Present results suggest that AMPK is not immediately recruited in case of metabolic perturbations (including in muscle and despite the large increase in plasma NEFA levels). This conclusion is also supported by the absence of AMPK activation in chicken brain, liver, or skeletal muscle in response to a 24-h fast; AMPK was, however, activated in muscle after a 48-h fast (Proszkowiec-Weglarz et al. 2006). In contrast, in the ovary of several species, including hen, AMPK activity varies during follicle development, independently of nutrition level (Dupont et al. 2008). In the present study, it was of interest to investigate whether the expression of some genes and proteins, known as insulin sensitive in mammals, had been altered in the liver or the muscle following insulin privation (5hrfed-Ab).

In the liver, mRNA levels of several transcription factors were altered by insulin privation. Egr1 (a zinc finger protein) is an immediate early transcription factor expressed in multiple tissues and cell types (Sukhatme et al. 1987). It was selectively decreased in the 'diabetic' status at $5 \mathrm{~h}$ but not by 
the 5-h fasting period. Interestingly, turning off the insulin cascade is not sufficient to decrease Egr1 expression since fasting did turn the cascade off without inhibiting Egr1 expression in the present conditions, which suggests a complex control of Egr1 expression. This, however, further supports the insulin specificity for the control of Egr1, which is a vital transcription factor for many genes. Several studies implicate Egr1 in the control of hepatic malic enzyme and A1 apolipoprotein genes in rat and human cells respectively (Kilbourne et al. 1990, Barroso et al. 1999). However, in the present study, changes in Egr1 messenger are most likely not involved in the changes observed for the lipogenic pathway (see next paragraph), since the lipogenic pathway was altered after both insulin privation or fasting.

Insulin privation and 5-h fasting decreased three other transcription factors in the liver, namely $\operatorname{PPAR} \gamma, \operatorname{SREBP} 1$, and THRSP $\alpha$ (Spot14), to about the same extent. Other PPAR family members were unchanged. Most likely, the changes in SREBP1 and PPAR $\gamma$ were coordinated, and accounted for the inhibition of FASN gene expression. Liver is the lipogenic organ in chickens (Simon 1989) and SREBP1 control of lipogenesis has been clearly demonstrated (Gondret et al. 2001). Importantly, both insulin privation and fasting were able to rapidly decrease the total amount of the SREBP1 protein, most likely accounting for the decrease in PPAR $\gamma$ expression. The present results on SREBP1 messenger and protein following insulin privation are the mirror image of changes observed in 24-h fasted-5-h re-fed chickens (Zhang \& Hillgartner 2004). Whether THRSP $\alpha$ expression is also dependent on SREBP1 is not yet clear. In addition to control by other transcriptional factors, THRSP $\alpha$ mRNA levels are regulated by $\mathrm{T}_{3}$ and, most likely, by pancreatic hormones in the present study and in the rat (Kinlaw et al. 1987). In the liver, THRSP $\alpha$ is differentially expressed in chicken lines exhibiting large differences in fat content and is dependent on the thyroid hormone status (Wang et al. 2007a,b). It is also present in adipose tissue (Wang et al. 2007a,b), though chicken adipocytes are not considered as active lipogenic sites (Simon 1989). The decrease in liver THRSP $\alpha$ messenger is very likely also to contribute to the inhibition of FASN gene expression since this factor is involved in the control of lipogenic enzymes (Roder et al. 2000). Rat hepatocytes, transfected with a spot 14 antisense oligonucleotide, express decreased mRNA levels in enzymes involved in the lipogenic pathway, including FASN (Kinlaw et al. 1995).

Insulin privation (and fasting) disturbed several components of the endocrine or metabolic systems. Deiodinases are seleno-enzymes that regulate $\mathrm{T}_{3}$ availability in peripheral tissues. Among them, liver D2-deiodinase expression was decreased while D3-deiodinase expression was increased, which would account for the reduction in plasma $T_{3}$. Such concomitant perturbations should rapidly inhibit the lipogenic pathway, since a potent and positive synergy occurs between $\mathrm{T}_{3}$ and insulin at several steps (references in Simon 1989). The present results suggest that the fine tuning of thyroid hormone metabolism is also insulin and most likely glucagon dependent in addition to other endocrine and nutritional controls (Darras et al. 2006). The hepatic adiponectin system (R2 and ligand) remained unaltered by insulin privation. In contrast, liver IGFBP1 mRNA clearly increased following insulin privation or 5-h fast. Therefore, rapid liver IGFBP1 synthesis should contribute to the increase in plasma IGFBP1 protein. Present and previous (Beccavin et al. 1999) observations make this protein a typical IGFBP1 protein, which is increased in mammals as a complication of diabetes. Under many circumstances, IGFBP-1 is inversely related to insulin concentration in human. In most strains of IGFBP-1 transgenic mice, fasting hyperglycemia, impaired glucose tolerance, and a modest insulin resistance in skeletal muscle and liver develop (Rajkumar et al. 1996).

In mammals, one of the major roles of insulin in the liver is stimulation of the synthesis and activity of GK (Narkewicz et al. 1990). The existence of a typical GK and the nutritional regulation of its activity have only recently been demonstrated in chicken liver (Berradi et al. 2005). The present results show the insulin dependency of GK mRNA in the fed chicken liver and suggest a rapid glucagon inhibitory effect in the fasting state. In the absence of a functional cytosolic PEPCK activity in chicken liver (Tinker et al. 1983, i.e. the regulatory component of gluconeogenesis in mammals), the decrease in liver GK mRNA and protein in fed chicken following insulin privation should decrease liver glucose utilization and contribute to the development of marked hyperglycemia. Indeed, it has been shown that GK knockout mice display mild basal hyperglycemia and exhibit a profound defect in glucose turnover (Postic et al. 1999).

In leg muscles, insulin privation altered only a few of the gene considered in the present study. As in the liver, muscle Egr1 mRNA was decreased by insulin privation at $5 \mathrm{~h}$ and not by fasting. PPAR $\beta \delta$ and atrogin- 1 mRNAs were increased by insulin privation but also by fasting. In another study, atrogin-1 mRNA increased then decreased in chicken muscle along with a 24-h fasting-2-h re-feeding experiment, most likely under the control of the Akt and FOXO-1 pathways (Nakashima et al. 2006). In a quail fibroblast cell line (QT6 cells), atrogin-1 transcript was inhibited at $5 \mathrm{~h}$ following insulin exposure with an early stimulation of Akt phosphorylation (Tesseraud et al. 2007c). Herein, fasting modified the expression of MURF1 and avUCP in muscle. Both atrogin-1 and MURF1 are muscle-specific atrogenes involved in the regulation of ubiquitin/proteasome-mediated proteolysis (Lecker 2003). This suggests that fasting rapidly induces proteolysis in chicken muscle. In the fed state, insulin would stimulate muscle protein accretion by inhibiting proteolysis through inhibition of atrogin-1 expression, in addition to stimulating cell amino transport and protein synthesis. Expression of other transcription factors (PGC1 $\alpha, \operatorname{PPAR} \alpha$, PPAR $\gamma$, SREBP1, and THRSP $\alpha$ ) was not altered in muscle following insulin privation. In the present study, insulin privation induced a large increase in plasma NEFA, albeit the abundance of avUCP mRNA in muscle was not affected. Therefore, the large increase in muscle avUCP mRNA 
induced by the 5-h fast might rely only partly on the increase in fatty acid availability. Until now, avUCP (the unique UCP thus far identified in chicken) has been involved in thermogenesis, fatty acid transport, and control of superoxide production in muscle mitochondria (Collin et al. 2005, Abe et al. 2006).

In mammals, skeletal muscles clear large amounts of plasma glucose during anabolic phases (DeFronzo et al. 1992). The existence of typical Glut4 glucose transporters is still under debate in chickens and recently in sparrows (Sweazea \& Braun 2006), which could come from the lack of cross-reactivity of antibodies directed against mammalian Glut4s. The existence of a functional and Glut4-related isoform of transporter has been suggested only in ducks (Thomas-Delloye et al. 1999). A Glut4 homolog has not been identified in the chicken genome; however, the chicken genome has not been completely sequenced yet. To date, only Glut1, Glut2, Glut3, and Glut8 homologs from the 13 Glut isoforms found in mammals (Joost et al. 2002) have been identified in chickens (Seki et al. 2003). The existence of a functional insulin-dependent glucose transporter in chicken muscle has been strongly suggested in vivo using 2-deoxyglucose uptake following insulin injection, at least in some muscles (Nishiki et al. 2008, Tokushima et al. 2003). The large hyperglycemia observed after insulin privation in fed chickens in the present study also favors the existence of functional Glut4-related glucose transporters in chicken.

In conclusion, insulin signaling is peculiar in chicken muscle. An acute 'diabetic' status develops rapidly after insulin immuno-neutralization in fed chickens. Hyper-glucagonemia and low $\mathrm{T}_{3}$ are early hormonal perturbations in the absence of insulin signal. Expression of several genes involved in regulatory pathways or metabolisms appeared clearly insulin dependent in the liver and the muscle, evidencing pleiotropic effects of insulin in fed chicken.

\section{Acknowledgements}

We would like to thank K Gérard for animal care. This study was funded by INRA and INSERM. Authors declare that there is no conflict of interest.

\section{References}

Abe T, Mujahid A, Sato K, Akiba Y \& Toyomizu M 2006 Possible role of avian uncoupling protein in down-regulating mitochondrial superoxide production in skeletal muscle of fasted chickens. FEBS Letters $\mathbf{5 8 0}$ 4815-4822.

Adamo M, Simon J, Rosebrough RW, McMurtry JP, Steele NC \& LeRoith D 1987 Characterization of the chicken muscle insulin receptor. General and Comparative Endocrinology 68 456-465.

Akiba Y, Chida Y, Takahashi T, Ohtomo Y, Sato K \& Takahashi K 1999 Persistent hypoglycemia induced by continuous insulin infusion in broiler chickens. British Poultry Science 40 701-705.
Barroso I \& Santisteban P 1999 Insulin-induced early growth response gene (Egr-1) mediates a short term repression of rat malic enzyme gene transcription. Journal of Biological Chemistry 274 17997-18004.

Beccavin C, Chevalier B, Simon J \& Duclos MJ 1999 Circulating insulin-like growth factors (IGF-I and -II) and IGF binding proteins in divergently selected fat or lean chickens: effect of prolonged fasting. Growth Hormone and IGF Research 9 187-194.

Berradi H, Taouis M, Cassy S \& Rideau N 2005 Glucokinase in chicken (Gallus gallus). Partial cDNA cloning, immunodetection and activity determination. Comparative Biochemistry and Physiology Part B: Biochemistry and Molecular Biology 141 129-139.

Bigot K, Taouis M \& Tesseraud S 2003a Refeeding and insulin regulate P70S6K1 activity in chicken skeletal muscles. Journal of Nutrition 133 369-373.

Bigot K, Taouis M, Picard M \& Tesseraud S $2003 b$ Early post-hatching starvation delays p70 S6 kinase activation in the muscle of neonatal chicks. British Journal of Nutrition 90 1023-1029.

Bouzakri K, Roques M, Gual P, Espinosa S, Guebre-Egziabher F, Riou J-P, Laville M, Le Marchand-Brustel Y, Tanti JF \& Vidal H 2003 Reduced activation of phosphatidylinositol-3 kinase and increased serine 636 phosphorylation of insulin receptor substrate-1 in primary culture of skeletal muscle cells from patients with type 2 diabetes. Diabetes $\mathbf{5 2}$ 1319-1325.

Collin A, Cassy S, Buyse J, Decuypere E \& Damon M 2005 Potential involvement of mammalian and avian uncoupling proteins in the thermogenic effect of thyroid hormones. Domestic Animal Endocrinology 29 78-87.

Darras VM, Verhoelst CH, Reyns GE, Kühn ER \& Van der Geyten S 2006 Thyroid hormone deiodination in birds. Thyroid 16 25-35.

DeFronzo RA, Bonadonna RC \& Ferrannini E 1992 Pathogenesis of NIDDM. A balanced overview. Diabetes Care 15 318-368.

Duchêne S, Audouin E, Berri C, Dupont J \& Tesseraud S 2008a Tissuespecific regulation of S6K1 by insulin in chickens divergently selected for growth. General and Comparative Endocrinology 156 190-198.

Duchêne S, Audouin E, Crochet S, Duclos MJ, Dupont J \& Tesseraud S $2008 b$ Involvement of the ERK2 MAPK pathway in insulin-induced P70S6K1 activation in avian cells. Domestic Animal Endocrinology 34 63-73.

Duchêne S, Métayer S, Audouin E, Bigot K, Dupont J \& Tesseraud S 2008 c Refeeding and insulin activate the AKT/p70S6 kinase pathway without affecting IRS1 tyrosine phosphorylation in chicken muscle. Domestic Animal Endocrinology 34 1-13.

Dupont J, Derouet M, Simon J \& Taouis M 1998a Nutritional state regulates insulin receptor and IRS-1 phosphorylation and expression in chicken. American Journal of Physiology 274 E309-E316.

Dupont J, Derouet M, Simon J \& Taouis M $1998 b$ Effect of nutritional state on the formation of a complex involving insulin receptor IRS-1, the $52 \mathrm{kDa}$ Src homology/collagen protein (Shc) isoform and phosphatidylinositol 3'-kinase activity. Biochemical Journal 335 293-300.

Dupont J, Derouet M, Simon J \& Taouis M 1998c Corticosterone alters insulin signaling in chicken muscle and liver at different steps. Journal of Endocrinology 162 67-76.

Dupont J, Chen J, Derouet M, Simon J, Leclercq B \& Taouis M 1999 Metabolic differences between genetically lean and fat chickens are partly attributed to the alteration of insulin signaling in liver. Journal of Nutrition 129 1937-1944

Dupont J, Dagou C, Derouet M, Simon J \& Taouis M 2004 Early steps of insulin receptor signaling in chicken and rat: apparent refractoriness in chicken muscle. Domestic Animal Endocrinology 26 127-142.

Dupont J, Chabrolle C, Ramé C, Tosca L \& Coyral-Castel S 2008 Role of the peroxisome proliferator-activated receptors, adenosine monophosphateactivated kinase and adiponectin in the ovary. PPAR Research ID: 176275

Gondret F, Ferré P \& Dugail I 2001 ADD-1/SREBP-1 is a major determinant of tissue differential lipogenic capacity in mammalian and avian species. Journal of Lipid Research 42 106-113.

Joost HG, Bell GI, Best JD, Birnbaum MJ, Charron MJ, Chen YT, Doege H, James DE, Lodish HF, Moley KH et al. 2002 Nomenclature of the GLUT/SLC2A family of sugar/polyol transport facilitators. American Journal of Physiology 282 E974-E976. 
Kilbourne EJ, Widom R, Harnish DC, Malik S \& Karathanasis SK 1990 Involvement of early growth response factor Egr-1 in apolipoprotein AI gene transcription. Journal of Biological Chemistry 270 7004-7010.

Kinlaw WB, Perez-Castillo AM, Fish LH, Mariash CN, Schwartz HL \& Oppenheimer JH 1987 Interaction of dietary carbohydrate and glucagon in regulation of rat hepatic messenger ribonucleic acid S14 expression: role of circadian factors and $3^{\prime}, 5^{\prime}$-cyclic adenosine monophosphate. Molecular Endocrinology 9 609-613

Kinlaw WB, Church JL, Harmon J \& Mariash CN 1995 Direct evidence for a role of the 'spot 14' protein in the regulation of lipid synthesis. Journal of Biological Chemistry 270 16615-16618.

Lecker SH 2003 Ubiquitin-protein ligases in muscle wasting: multiple paralle pathways? Current Opinion in Clinical Nutrition and Metabolic Care 3 271-275.

Long YC \& Zierath JR 2006 AMP-activated protein kinase signaling in metabolic regulation. Journal of Clinical Investigation 116 1776-1783.

Mirsky IA, Jinks R \& Perisutti G 1964 Production of diabetes mellitus in the duck by insulin antibodies. American Journal of Physiology 206 133-135.

Nakashima K, Yakabe Y, Yamazaki M \& Abe H 2006 Effects of fasting and refeeding on expression of atrogin-1 and Akt/FOXO signaling pathway in skeletal muscle of chicks. Bioscience, Biotechnology, and Biochemistry 70 2775-2778.

Narkewicz MR, Iynedjian PB, Ferre P \& Girard J 1990 Insulin and triiodothyronine induce glucokinase $\mathrm{mRNA}$ in primary cultures of neonatal rat hepatocytes. Biochemical Journal 271 585-589.

Nishiki Y, Kono T, Fukao K, Sato K, Takahashi K, Toyomizu M \& Akiba Y 2008 Nitric oxide (NO) is involved in modulation of non-insulin mediated glucose transport in chicken skeletal muscles. Comparative Biochemistry and Physiology Part B: Biochemistry and Molecular Biology 149 101-107.

Pfaffl MW 2001 A new mathematical model for relative quantification in realtime RT-PCR. Nucleic Acids Research 29 e45.

Postic C, Shiota M, Niswender KD, Jetton TL, Chen Y, Moates JM, Shelton KD, Lindner J, Cherrington AD \& Magnuson MA 1999 Dual roles for glucokinase in glucose homeostasis as determined by liver and pancreatic beta cell-specific gene knock-outs using Cre recombinase. Journal of Biological Chemistry 274 305-315.

Proszkowiec-Weglarz M, Richards MP, Ramachandran R \& McMurtry J 2006 Characterization of the AMP-activated protein kinase pathway in chickens. Comparative Biochemistry and Physiology Part B: Biochemistry and Molecular Biology 143 92-106.

Rajkumar K, Krsek M, Dheen ST \& Murphy LJ 1996 Impaired glucose homeostasis in insulin-like growth factor binding protein-1 transgenic mice. Journal of Clinical Investigation 98 1818-1825.

Roder K, Wolf SS \& Schweizer M 2000 Dependence of rat spot14 promoter activity on NF-Y binding to the inverted CCAAT-element at -100 . Bioscience, Biotechnology and Biochemistry 64 848-851.

Ruffier L, Simon J \& Rideau N 1998 Isolation of functional glucagon islets of Langerhans from the chicken pancreas. General and Comparative Endocrinology 112 153-162.

Seki Y, Sato K, Kono T, Abe H \& Akiba Y 2003 Broiler chickens (Ross strain) lack insulin-responsive glucose transporter GLUT4 and have GLUT8 cDNA. General and Comparative Endocrinology 133 80-87.

Simon J 1989 Chicken as a useful species for the comprehension of insulin action. Critical Reviews in Poultry Biology 2 121-148.

Simon J \& Taouis M 1993 The insulin receptor in chicken tissues. In Avian Endocrinology, pp 177-188. Ed. PJ Sharp. Bristol: Journal of Endocrinology Ltd.

Simon J, Derouet M \& Gespach C 2000 An anti-insulin serum, but not a glucagon antagonist, alters glycemia in fed chickens. Hormone and Metabolic Research 32 139-141.

Sukhatme VP, Kartha S, Toback FG, Taub R, Hoover RG \& Tsai-Morris CH 1987 A novel early growth response gene rapidly induced by fibroblast, epithelial cell and lymphocyte mitogens. Oncogene research 1 343-355.

Sweazea KL \& Braun EJ 2006 Glucose transporter expression in English sparrows (Passer domesticus). Comparative Biochemistry and Physiology Part B: Biochemistry and Molecular Biology 144 263-270.
Taniguchi CM, Emanuelli B \& Kahn CR 2006a Critical nodes in signalling pathways: insights into insulin action. Nature Reviews. Molecular Cell Biology 2 85-96.

Taniguchi CM, Tran TT, Kondo T, Luo J, Ueki K, Cantley LC \& Kahn CR 2006 bhosphoinositide 3-kinase regulatory subunit p85alpha suppresses insulin action via positive regulation of PTEN. PNAS 103 12093-12097.

Taniguchi CM, Aleman JO, Ueki K, Luo J, Asano T, Kaneto H, Stephanopoulos G, Cantley LC \& Kahn CR 2007 The p85alpha regulatory subunit of phosphoinositide 3-kinase potentiates c-Jun N-terminal kinasemediated insulin resistance. Molecular and Cellular Biology 8 2830-2840.

Taouis M, Taylor SI \& Reitman M 1996 Cloning of the chicken insulin receptor susbtrate 1 gene. Gene 178 51-55.

Terauchi Y, Tsuji Y, Satoh S, Minoura H, Murakami K, Okuno A, Inukai K, Asano T, Kaburagi Y, Ueki K et al. 1999 Increased insulin sensitivity and hypoglycaemia in mice lacking the p85 alpha subunit of phosphoinositide 3-kinase. Nature Genetics 21 230-235.

Tesseraud S, Bigot K \& Taouis M 2007a Amino acid availability regulates P70S6K1 and protein synthesis in avian insulin-insensitive QM7 myoblasts. FEBS Letters 540 176-180.

Tesseraud S, Métayer S, Duchêne S, Bigot K, Grizard J \& Dupont J 2007 b Regulation of protein metabolism by insulin: value of different approaches and animal models. Domestic Animal Endocrinology 33 123-142.

Tesseraud S, Métayer-Coustard S, Boussaid S, Crochet S, Audouin E, Derouet M \& Seiliez I 2007c Insulin and amino acid availability regulate atrogin-1 in avian QT6 cells. Biochemical and Biophysical Research Communications 357 181-186.

Thomas-Delloye V, Marmonier F, Duchamp C, Pichon-Georges B, Lachuer J, Barré H \& Crouzoulon G 1999 Biochemical and functional evidences for a GLUT-4 homologous protein in avian skeletal muscle. American Journal of Physiology 277 R1733-R1740.

Tinker DA, Kung M, Brosnan JT \& Herzberg GR 1983 Avian phosphoenolpyruvate carboxykinase: effect of age, starvation and photoperiod. International Journal of Biochemistry 15 1225-1230.

Tokushima Y, Sulistiyanto B, Takahashi K \& Akiba Y 2003 Insulin-glucose interactions characterized in newly hatched broiler chicks. British Poultry Science 44 746-751.

Tokushima Y, Takahashi K, Sato K \& Akiba Y 2005 Glucose uptake in vivo in skeletal muscles of insulin-injected chicks. Comparative Biochemistry and Physiology Part B: Biochemistry and Molecular Biology 141 43-48.

Ueki K, Yballe CM, Brachmann SM, Vicent D, Watt JM, Kahn CR \& Cantley LC 2002 Increased insulin sensitivity in mice lacking p85beta subunit of phosphoinositide 3-kinase. PNAS 99 419-424.

Unson CG, Gurzenda EM \& Merrifield RB 1989 Biological activities of desHis1[Glu9]glucagon amide, a glucagon antagonist. Peptides 10 1171-1177.

Wang HB, Li H, Wang QG, Zhang XY, Wang SZ, Wang YX \& Wang XP $2007 a$ Profiling of chicken adipose tissue gene expression by genome array. BMC Genomics 8193

Wang X, Carré W, Saxton AM \& Cogburn LA $2007 b$ Manipulation of thyroid status and/or GH injection alters hepatic gene expression in the juvenile chicken. Cytogenetic and Genome Research 117 174-188.

White MF \& Kahn CR 1994 The insulin signaling system. Journal of Biological Chemistry 269 1-4.

Zhang Y \& Hillgartner FB 2004 Starvation and feeding a high-carbohydrate, low-fat diet regulate the expression sterol regulatory element-binding protein-1 in chickens. Journal of Nutrition 134 2205-2210.

Received in final form 18 March 2008

Accepted 27 March 2008

Made available online as an Accepted Preprint 27 March 2008 